\title{
Effect of Foliar Application of Titanium Dioxide on Bacterial Blight of Geranium and Xanthomonas Leaf Spot of Poinsettia
}

\author{
David J. Norman ${ }^{\mathbf{1} 2}$ and Jianjun Chen \\ Department of Plant Pathology, and Professor, Department of Environmental \\ Horticulture, respectively, University of Florida, Institute of Food and \\ Agricultural Sciences, Mid-Florida Research and Education Center, 2725 \\ Binion Road, Apopka, FL 32703
}

Additional index words. bactericide, Euphorbia pulcherrima, Pelargonium

\begin{abstract}
This study is the first report of using titanium dioxide $\left(\mathrm{TiO}_{2}\right)$ to control Xanthomonas bacterial blight on geranium and leaf spot on poinsettia. Potted zonal geranium 'Patriot Bright Violet' and poinsettia 'Snowcap' were grown in a greenhouse and treated with a foliar spray of $\mathrm{TiO}_{2}$ at 25 and $75 \mathrm{~mm}$, respectively, twice. Titaniumtreated and control geranium plants were inoculated with Xanthomonas hortorum pv. pelargonii and poinsettias were inoculated with Xanthomonas axonopodis pv. poinsettiicola. The experiment was repeated once. The numbers of lesions on geranium leaves sprayed with $\mathrm{TiO}_{2}$ at 25 and $75 \mathrm{~mm}$ were $53 \%$ and $67 \%$, respectively, less than in control plants in the first trial, but there were no significant differences among treatments in the second trial. Results on poinsettia, however, showed significant decrease in lesion numbers in both trials. Plants treated with $\mathrm{TiO}_{2}$ at 25 and 75 m showed $85 \%$ and $93 \%$ reduction in lesions, respectively, in the first trial and $87 \%$ and $92 \%$ reduction in lesions in the second trial. No symptoms of phytotoxicity were observed. This study suggests that $\mathrm{TiO}_{2}$ has potential as an alternative to currently labeled products for controlling Xanthomonas bacterial blight in geranium and leaf spot on poinsettia.
\end{abstract}

Bacterial diseases cause significant economic losses in the ornamental and floricultural industries (Daughtrey and Benson, 2005). In today's competitive marketplace, plants with spotted leaves, retarded growth, or wilted stems are not acceptable to consumers. To produce disease-free plant materials, modern facilities rely on strict sanitation and cultural practices to prevent bacterial outbreaks. Among them, culture indexing is a commonly used practice (Raju and Olson, 1985). Indexing programs can systematically detect and eliminate propagation materials contaminated with pathogens to ensure that only healthy plant materials are used for production (Klopmeyer, 2000; Oglevee-O'Donovan, 1993). However, even with strict sanitation guidelines, bacteria can still enter production facilities through contaminated seeds, propagative materials, aerosols, wind, alternate hosts, human contacts, or human error (Daughtrey et al., 1995). In many cases, the initial mode of introduction of the pathogen into the production facility is never identified. Once introduced, bacteria become established and spread rapidly through contact or through irrigation, causing significant crop loss (Daughtrey and Benson, 2005).

Received for publication 28 Sept. 2010. Accepted for publication 10 Dec. 2010.

${ }^{1}$ Associate Professor.

${ }^{2}$ To whom reprint requests should be addressed; e-maildjn@ufl.edu.
Bacterial blight on zonal geranium (Pelargonium $\times$ hortorum) is considered to be the most serious problem limiting geranium production (Nameth et al., 1999). Bacteria initially enter plants through stomates, pores, or small wounds on leaf surfaces. Symptoms of this disease may vary greatly between cultivars of geranium. First visible symptoms are usually small, dark brown, sunken leaf spots. In some cultivars, however, symptoms are expressed with formation of $\mathrm{V}$-shaped yellow lesions that occur in the leaf edge and taper toward the center of the leaf. Plants sometimes become systemically infected and die.

The use of culture-indexed plants greatly reduces the incidence of bacterial blight in geranium production. However, if greenhouse temperatures are cool and humidity low, infected geraniums can remain asymptomatic for months. Increasing temperatures or environmental stress will eventually trigger wilt and death of systemically infected plants. Most index block production systems use drip irrigation systems to keep foliage dry and limit spread between plants.

Xanthomonas leaf spot of poinsettia (Euphorbia pulcherrima) is another important floral crop disease. It was first described in India in 1951 (Patel et al., 1951) and has since been found in nearly every country where poinsettia is produced. Initial symptoms are small pinpoint lesions on leaves. In some cultivars, these lesions remain small, whereas in others, they coalesce to form larger angular leaf spots. Spread of Xanthomonas axonopodis pv. poinsettiicola within production facilities is similar to that observed for Xanthomonas hortorum pv. pelargonii on geranium. Strict sanitation is considered the best method of excluding this disease from production (Benson et al., 2002). However, because poinsettia is predominantly propagated through cuttings, overhead irrigation allows for easy spread of Xanthomonas during propagation.

In addition to strict sanitation, bactericides are used for controlling Xanthomonas species in geranium and poinsettia. The most commonly used bactericides contain copper, manganese, and/or zinc, but very few bactericidal control products are effective against established infections (Benson et al., 2002). Development of pathogen resistance to chemicals is also a concern. Recently, several studies have suggested that $\mathrm{TiO}_{2}$ application suppresses bacterial and fungal pathogens of field crops. In cereal crops, severity and incidence of Curvularia leaf spot (Curvularia lunata) and bacterial leaf blight (Xanthomonas oryzae pv. oryzae) were reduced with $\mathrm{TiO}_{2}$ applications (Chao and Choi, 2005). Similar results were observed in field applications of $\mathrm{TiO}_{2}$ on cowpea, in which significant reduction of both incidence and severity of Cercospora leaf spot and brown blotch was documented (Owolade and Ogunleti, 2008). Bowen et al. (1992) were able to control both downy and powdery mildew on grapes with combinations of $\mathrm{TiO}_{2}$ with aluminum and silica. Yao et al. (2007) showed the potential of using $\mathrm{TiO}_{2}$ in recycled irrigation water to eliminate both fungal and bacterial pathogens. It is believed that $\mathrm{TiO}_{2}$ destroys cell membranes of pathogens, causing leakage and death through oxidation. Despite this strong oxidizing power, $\mathrm{TiO}_{2}$ has been shown to be safe on plant surfaces (Frazer, 2001).

As far as we know, there has been no report on $\mathrm{TiO}_{2}$ application to floricultural crops for disease control. The objective of this study was to determine if $\mathrm{TiO}_{2}$ could be used to control Xanthomonas hortorum pv. pelargonii on geranium and Xanthomonas axonopodis pv. poinsettiicola on poinsettia. Both geraniums and poinsettias are among the most popular floricultural crops in the United States with wholesale values at $\$ 9,385,000$ and $\$ 145,088,000$ in 2009 , respectively (USDA, 2009).

\section{Materials and Methods}

Plugs of poinsettia 'Snowcap' and zonal geranium 'Patriot Bright Violet' were obtained from Paul Ecke Ranch, Encinitas, CA, and planted into $15-\mathrm{cm}$ diameter pots containing Fafard \#2 mix (Conrad Fafard, Inc., Agawam, MA). A total of 150 plants was potted per genus. All plants were fertilized initially with $1.5 \mathrm{~g}$ of Osmocote - Plus $\left(15 \mathrm{~N}-9 \mathrm{P}_{2} \mathrm{O}_{5}-12\right.$ $\mathrm{K}_{2} 0$ ) (The Scotts Co., Marysville, $\mathrm{OH}$ ) and were grown in a greenhouse with temperatures maintained between 27 and $35^{\circ} \mathrm{C}$ and maximum photosynthetic photon flux density of $475 \mu \mathrm{mol} \cdot \mathrm{m}^{-2} \cdot \mathrm{s}^{-1}$ with a natural photoperiod. Plants were allowed to become established for 1 month before $\mathrm{TiO}_{2}$ application. 
Sixty plants of each genus were randomly selected from the 150. Two fresh solutions at 25 and $75 \mathrm{~mm} \mathrm{TiO}_{2}$ (Sigma-Aldrich, St. Louis, $\mathrm{MO}$ ) were prepared. To avoid precipitation, the solutions were immediately used for spraying onto plants right after $\mathrm{TiO}_{2}$ was dissolved. Leaves of 20 plants were sprayed with deionized water, another 20 plants with $25 \mathrm{~mm} \mathrm{TiO}_{2}$ solution, and the remaining 20 with $75 \mathrm{~mm}$ $\mathrm{TiO}_{2}$ solution using hand pump sprayers until runoff. One week after the first foliar spray, fresh $\mathrm{TiO}_{2}$ solutions were made, and the 60 plants were again subjected to the same treatments as before.

Bacterial strains Xanthomonas hortorum pv. pelargonii (X575) and Xanthomonas axonopodis pv. poinsettiicola (X1729) were selected from the Bacteriological Collection at the University of Florida's Mid-Florida Research and Education Center, Apopka, FL. Both strains were isolated from their respective hosts and identified to pathovar level using FAME analysis. Inoculum of each strain was prepared by suspending 24-hr-old bacteria cultured on Difco nutrient agar amended with $5 \%$ sucrose in saline $(8.5 \mathrm{~g} / \mathrm{L} \mathrm{NaCl})$ and spectrophotometrically adjusting $\left(\mathrm{A}_{600}\right)$ the concentration to $1 \times 10^{5}$ colony-forming units $(\mathrm{cfu}) / \mathrm{mL}$ and $1 \times 10^{8} \mathrm{cfu} / \mathrm{mL}$ for geranium and poinsettia, respectively.

There were a total of six treatments for each plant genus: 1) deionized water spray without pathogen inoculation; 2) deionized water spray with pathogen inoculation; 3) $25 \mathrm{~mm} \mathrm{TiO}_{2}$ spray without pathogen inoculation; 4) $75 \mathrm{~mm}$ $\mathrm{TiO}_{2}$ spray without pathogen inoculation; 5) $25 \mathrm{~mm} \mathrm{TiO}_{2}$ spray with pathogen inoculation; and 6) $75 \mathrm{~mm} \mathrm{TiO}_{2}$ spray with pathogen inoculation. Inoculum was applied to the foliage of test plants using hand pump sprayers $24 \mathrm{~h}$ after the second foliar spray treatment. Immediately after inoculation, plants were bagged in clear polyethylene bags for $24 \mathrm{~h}$ to maintain high relative humidity and promote infections. The experiment was arranged as a completely randomized design with 10 plants in each treatment.

Lesion numbers on each plant were counted 12 and $16 \mathrm{~d}$ after inoculation for geranium and poinsettia, respectively. Plant shoots of all plants were harvested 3 weeks after X575 inoculation onto geranium and $30 \mathrm{~d}$ after X1729 inoculation onto poinsettia by cutting the stem at the base (media surface). Shoots were dried to a constant mass at $85^{\circ} \mathrm{C}$, and shoot dry weights (g) were recorded. Lesion and dry weight data were statistically compared using analysis of variance and Tukey's least significant difference. After the completion of the experiment, an additional 60 plants of each genus were selected from the remaining 90 plants, and the trial was repeated. The experimental procedure, data collection, and analysis were the same as described in the first experiment.

\section{Results and Discussion}

In the first trial with Xanthomonas bacterial blight on zonal geraniums, plants in both treatment levels of $\mathrm{TiO}_{2}$ exhibited significantly less disease than the disease control $(P \leq 0.5)$.
The numbers of lesions on leaves sprayed with $\mathrm{TiO}_{2}$ at 25 and $75 \mathrm{~mm}$ were $53 \%$ and $67 \%$ lower than those of control plants, respectively (Table 1). In the second test, there was no significant reduction in leaf spot numbers with either rate of $\mathrm{TiO}_{2}$. No phytotoxicity was observed. Foliar spray of $\mathrm{TiO}_{2}$ strongly suppressed Xanthomonas development on poinsettia. In the first trial, the number of lesions was $85 \%$ and $93 \%$ lower on leaves treated with 25 and $75 \mathrm{~mm} \mathrm{TiO}_{2}$, respectively, compared with those of the control plants.

Similar results were obtained in the second trial, in which lesion numbers on leaves sprayed with $25 \mathrm{~mm}$ and $75 \mathrm{~mm} \mathrm{TiO}_{2}$ were $87 \%$ and $92 \%$ lower, respectively, than those in the control plants (Table 2). There were no dry weight differences among treatments in poinsettia.

In commercial floral crop production, disease management practices often include strict sanitation along with bactericide application. Key ingredients of many bactericides are copper, manganese, and/or zinc (Benson et al., 2002); titanium has not previously been considered as an ingredient of bactericides. Our study documented that foliar spray of $\mathrm{TiO}_{2}$ can provide up to $67 \%$ control of leaf lesions in geranium under some conditions. This magnitude of control is comparable to or better than some commercial products previously trialed (Norman, 2009). Commercial products used for control of Xanthomomas leaf spot in poinsettia contain copper. As pointed out by Benson et al. (2002), these products may be partially effective in controlling this pathogen but are rarely effective in stopping an outbreak. Our study showed that $\mathrm{TiO}_{2}$ application reduced lesions on poinsettia by $85 \%$ to $93 \%$. Such effective- ness has not been reported in controlling leaf spot of poinsettia. Because this is the first study of $\mathrm{TiO}_{2}$ application in suppression of both Xanthomonas hortorum pv. pelargonii and Xanthomonas axonopodis pv. poinsettiicola, it is possible that further research to finetune the concentrations, application times, and intervals might improve the effectiveness of $\mathrm{TiO}_{2}$ in controlling the two pathogens.

In our study, $\mathrm{TiO}_{2}$ at the applied concentrations did not cause phytotoxicity. Plant dry weights were similar among the treatments; these results are different from significant increases observed in plant growth and yield of cowpea (Owolade and Ogunleti, 2008). An explanation could be that in our experiments plants were harvested too early and we did not allow time for growth suppression to be evident. Additionally, there were differences in lesion numbers in the controls between the first trial and second trial in both plant genera. The lower lesion numbers in the controls in the second trial could have been the result of lower humidity conditions after inoculation. The second trial was conducted at a time of high outside temperatures that resulted in continuous running of air conditioners.

Foliar application of $\mathrm{TiO}_{2}$ in this study left a white residue on the leaf surfaces of both crops. This residue would not be a concern early in the plant production cycle of either geranium or poinsettia. However, it would have a negative impact with consumers if it appeared on the final product. Similar leaf residue problems exist with currently registered products that contain copper hydroxide or manganese. The problem with unsightly residues suggests that a new discipline within biopesticide science using nanomolecules as a delivery system to

Table 1. Effect of $\mathrm{TiO}_{2}$ on plant dry weight and control of lesion number after inoculation of Xanthomonas hortorum pv. pelargonii on zonal geranium.

\begin{tabular}{|c|c|c|c|c|}
\hline \multirow[b]{2}{*}{ Treatment $^{\mathrm{x}}$} & \multicolumn{2}{|c|}{ Expt. 1} & \multicolumn{2}{|c|}{$\begin{array}{r}\text { Expt. } 2 \\
\end{array}$} \\
\hline & Lesion no. ${ }^{y}$ & Dry wt (g) & Lesion no. & Dry wt $(\mathrm{g})$ \\
\hline Non-inoculated control & $0.0 \mathrm{a}^{\mathrm{z}}$ & $3.5 \mathrm{ab}$ & $0.0 \mathrm{a}$ & $4.8 \mathrm{a}$ \\
\hline Inoculated control & $110.0 \mathrm{~b}$ & $4.0 \mathrm{ab}$ & $44.0 \mathrm{~b}$ & $5.2 \mathrm{a}$ \\
\hline Inoculated $\mathrm{TiO}_{2}(25 \mathrm{~mm})$ & $52.0 \mathrm{a}$ & $4.5 \mathrm{~b}$ & $54.0 \mathrm{~b}$ & $4.4 \mathrm{a}$ \\
\hline Inoculated $\mathrm{TiO}_{2}(75 \mathrm{~mm})$ & $36.0 \mathrm{a}$ & $3.0 \mathrm{ab}$ & $26.0 \mathrm{ab}$ & $4.6 \mathrm{a}$ \\
\hline Non-inoculated $\mathrm{TiO}_{2}(25 \mathrm{~mm})$ & $0.0 \mathrm{a}$ & $3.7 \mathrm{ab}$ & $0.0 \mathrm{a}$ & $5.1 \mathrm{a}$ \\
\hline Non-inoculated $\mathrm{TiO}_{2}(75 \mathrm{~mm})$ & $0.0 \mathrm{a}$ & $2.9 \mathrm{a}$ & $0.0 \mathrm{a}$ & $5.4 \mathrm{a}$ \\
\hline
\end{tabular}

${ }^{\text {zMean separation within columns by analysis of variance and Tukey's least significant difference }}$ $(P \leq 0.5)$

${ }^{y}$ No. in a column followed by the same letter are not different at the $5 \%$ level.

${ }^{\mathrm{x}}$ Ten plants in each treatment.

$\mathrm{TiO}_{2}=$ titanium dioxide.

Table 2. Effect of $\mathrm{TiO}_{2}$ on plant dry weight and control of lesion number after inoculation of Xanthomonas axonopodis pv. poinsettiicola on poinsettia.

\begin{tabular}{|c|c|c|c|c|}
\hline \multirow[b]{2}{*}{ Treatment $^{\mathrm{x}}$} & \multicolumn{2}{|c|}{ Expt. 1} & \multicolumn{2}{|c|}{ Expt. 2} \\
\hline & Lesion no. ${ }^{y}$ & Dry wt $(\mathrm{g})$ & Lesion no. & Dry wt $(g)$ \\
\hline Non-inoculated control & $0.0 \mathrm{a}^{\mathrm{z}}$ & $15.0 \mathrm{a}$ & $0.0 \mathrm{a}$ & $28.7 \mathrm{a}$ \\
\hline Inoculated control & $118.0 \mathrm{~b}$ & $15.5 \mathrm{a}$ & $71.0 \mathrm{~b}$ & $28.5 \mathrm{a}$ \\
\hline Inoculated $\mathrm{TiO}_{2}(25 \mathrm{~mm})$ & $18.0 \mathrm{a}$ & $14.6 \mathrm{a}$ & $9.3 \mathrm{a}$ & $27.1 \mathrm{a}$ \\
\hline Inoculated $\mathrm{TiO}_{2}(75 \mathrm{~mm})$ & $8.0 \mathrm{a}$ & $14.9 \mathrm{a}$ & $6.0 \mathrm{a}$ & $25.9 \mathrm{a}$ \\
\hline Non-inoculated $\mathrm{TiO}_{2}(25 \mathrm{~mm})$ & $0.0 \mathrm{a}$ & $13.9 \mathrm{a}$ & $0.0 \mathrm{a}$ & $25.7 \mathrm{a}$ \\
\hline Non-inoculated $\mathrm{TiO}_{2}(75 \mathrm{~mm})$ & $0.0 \mathrm{a}$ & $14.7 \mathrm{a}$ & $0.0 \mathrm{a}$ & $26.0 \mathrm{a}$ \\
\hline
\end{tabular}

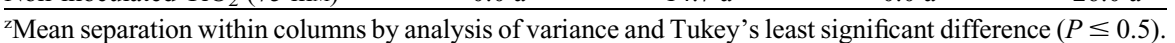

${ }^{y}$ No. in a column followed by the same letter are not different at the $5 \%$ level.

${ }^{\mathrm{x}}$ Ten plants in each treatment.

$\mathrm{TiO}_{2}=$ titanium dioxide. 
target bacterial pathogens might play an important role in the future. The use of nanoparticles would eliminate visible residue on floricultural crops as well as increase application efficiency and reduce element concentrations.

Titanium dioxide nanoparticles have been shown to possess a strong oxidation reaction, which can target organic compounds. These nanoparticles of $\mathrm{TiO}_{2}$ have been shown recently to be very effective in inactivating avian influenza virus (Cui et al., 2010). Nanoparticles of $\mathrm{TiO}_{2}$ have also been recommended for control of plant diseases (Cui et al., 2009).

\section{Literature Cited}

Benson, D.M., J.L. Hall, G.W. Moorman, M.L. Daughtrey, A.R. Chase, and K.H. Lamour. 2002. The history and diseases of poinsettia, the Christmas flower. Plant Health Prog. doi: 10.1094/PHP-202-0212-01-RV.

Bowen, P., J. Menzies, D. Ehret, L. Samuel, and A.D.M. Glass. 1992. Soluble silicon sprays inhibit powdery mildew development in grape leaves. J. Amer. Soc. Hort. Sci. 117:906-912.

Chao, S.-H.L. and H.-S. Choi. 2005. Method for providing enhanced photosynthesis. Korea Research Institute of Chemical Technology, Jeonju, South Korea. Bulletin.
Cui, H., J. Jiang, W. Gu, C. Sun, D. Wu, T. Yang, and G. Yang. 2010. Photocatalytic inactivation efficiency of anatase nano- $\mathrm{TiO}_{2}$ sol on the H9N2 avian influenza virus. Photochem. Photobiol. 86:1135-1139.

Cui, H., P. Zhang, and W. Gu. 2009. Application of anatase $\mathrm{TiO} 2$ sol derived from peroxotitannic acid in crop plant diseases control and growth regulation. Nanotech. Conf. and Expo 2009 (abstr.), 3-7 May, Houston TX.

Daughtrey, M.L. and D.M. Benson. 2005. Principles of plant health management for ornamental plants. Annu. Rev. Phytopathol. 43:141169.

Daughtrey, M.L., R.L. Wick, and J.L. Peterson. 1995. Compendium of flowering potted plant diseases. APS Press, St, Paul, MN.

Frazer, L. 2001. Titanium dioxide: Environmental white knight. Environ. Health Perspect. 109: 174-177.

Klopmeyer, M.J. 2000. Indexing for plant pathogens, p. 417-425. In: Trigiano, R.N. and D.J. Gray (eds.). Plant tissue culture concepts and laboratory exercises. 2nd Ed. CRC Press, Boca Raton, FL.

Miller, D.M. 2002. The taxonomy of Pelargonium species and cultivars, their origins and growth in the wild, p. 49-79. In: Lis-Balchin, M. (ed.). Geranium and pelargonium. Taylor \& Francis Group, New York, NY.
Nameth, S.T., M.L. Daughtrey, G.W. Moorman, and M.A. Sulzinski. 1999. Bacterial blight of geranium: A history of diagnostic challenges. Plant Dis. 83:204-212.

Norman, D. 2009. Managing the unmanageable: Treating bacterial diseases in flowering potted crops. p. 77-83. In: Bethke, J., S. Ludwig, and C. Palmer (eds.). 25th annual pest management conference. San Jose, CA.

Oglevee-O'Donovan, W. 1993. Culture indexing for vascular wilts and viruses, p. 277-286. In: White, J.E. (ed.). Geraniums I. Ball Publ. Society of American Florists, Geneva, IL.

Owolade, O.F. and D.O. Ogunleti. 2008. Effects of titanium dioxide on the diseases, development and yield of edible cowpea. J. Plant Protect. Res. 48:329-335.

Patel, M.K., V.V. Bhatt, and Y.S. Kulkarni. 1951. Three new bacterial diseases of plants from Bombay. Indian Phytopathol. 4:144-151.

Raju, B.C. and C.J. Olson. 1985. Indexing systems for producing clean stock for disease control in commercial floriculture. Plant Dis. 69:189192.

USDA. 2009. Floriculture crops 2009 summary. Washington, DC.

Yao, K.S., D.Y. Wang, W.Y. Ho, J.J. Yan, and K.C. Tzeng. 2007. Photocatalytic bactericidal effect of $\mathrm{TiO}_{2}$ thin film on plant pathogens. Surf. Coat. Tech. 201:6886-6888. 